\title{
EVALUATION OF ANTIMICROBIAL RESISTANCE OF HELICOBACTER PYLORI IN THE LAST 15 YEARS IN WEST POLAND
}

\author{
TOMASZ M. KARPIŃSKI ${ }^{1}$, EWA ANDRZEJEWSKA ${ }^{1}$, PIOTR EDER ${ }^{2}$, \\ KRZYSZTOF LINKE² and ANDRZEJ SZKARADKIEWICZ ${ }^{1 *}$ \\ ${ }^{1}$ Department of Medical Microbiology, Poznań University of Medical Sciences, \\ Wieniawskiego Str. 3, 61-712 Poznań, Poland \\ ${ }^{2}$ Department of Gastroenterology, Human Nutrition and Internal Diseases, \\ Poznań University of Medical Sciences, Przybyszewskiego Str. 49, 60-355 Poznań, Poland
}

(Received: 23 March 2015; accepted: 16 June 2015)

Increasing resistance to drugs represents a serious problem in treatment of infections with Helicobacter pylori, providing cause of frequent therapeutic failures. Present study aimed at analysis of changes in resistance of $H$. pylori to antibiotics in West Poland within the recent 15 years. 108 strains of $H$. pylori were analysed, isolated from gastric mucosa of adult patients. Group 1 involved 66 strains isolated in years of 1998/1999. Group 2 comprised 42 isolates obtained in years of 2013/2014. Susceptibility to amoxicillin (AMX), clarithromycin (CL), tetracycline (TC) and metronidazole (MTZ) was determined by E-test (AB Biodisc). All strains on both studied groups were susceptible to AMX. In group 1 all strains proved to be susceptible to TC, while $9 \%$ and $36 \%$ of tested strains were resistant to CL and MTZ, respectively. By contrast, in group 2,31\% and $83 \%$ of strains were resistant to CL and MTZ, respectively. In parallel, 14\% strains were found to be resistant to TC (according to EUCAST interpretations). In West Poland, within recent 15 years a dramatic increase was noted in $H$. pylori strains resistant to metronidazole. In parallel, a significant increase was noted in proportion of strains resistant to clarithromycin.

Keywords: Helicobacter pylori, antibiotic resistance, chronic gastritis, peptic ulcer disease, treatment

\section{Introduction}

Helicobacter pylori represents one of the most widespread pathogenic bacterial species affecting humans. Infections with $H$. pylori are common, burden-

\footnotetext{
*Corresponding author; E-mail: szkaradkiewicza@poczta.onet.pl
} 
ing around $50 \%$ of world populations [1]. In north European populations about $30 \%$ of adults are infected, whereas in south and east Europe the prevalence of H. pylori is often higher than $50 \%$. The highest prevalence of $H$. pylori amounting to $84.2 \%$ was reported in Portugal [2]. H. pylori represents an etiological factor of peptic ulcer disease, gastric mucosa-associated lymphoid tissue (MALT) lymphoma, chronic gastritis with intestinal metaplasia and of gastric adenocarcinoma [3]. Triple therapy including proton-pump inhibitor, amoxicillin and clarithromycin or metronidazole was generally accepted as the first-line therapy $[4,5]$. However, the therapy proved to be ineffective in up to $30-40 \%$ of patients $[6,7]$. An important predictor of the success of $H$. pylori eradication therapy is the antimicrobial susceptibility. In H. pylori manifestation of resistance to antibiotics varies geographically and undergoes dynamic alterations [8]. Therefore, several research institutions throughout the world monitor current drug resistance in H. pylori. Present study aimed at analysis of changes in resistance of H. pylori to antibiotics in West Poland within the recent 15 years.

\section{Materials and Methods}

\section{Bacterial isolates}

Evaluation of drug susceptibility was performed on the total of 108 strains of $H$. pylori originating from adult patients from West Poland. All the strains were isolated from gastric mucosa before treatment. Group 1 involved 66 strains isolated in years of 1998/1999. Group 2 comprised 42 isolates obtained in years of 2013/2014. Biopsies isolated from the prepyloric portion were immediately placed in a transport medium (Portagerm pylori; bioMerieux). The obtained biopsies were plated on Columbia agar supplemented with $7 \%$ of sheep blood and a set of antibiotics (H. pylori selective supplement Dent SR 147E; Oxoid). The incubation was performed in microaerophilic conditions (Generbag or Generbox microaer; bioMerieux) at the temperature of $37^{\circ} \mathrm{C}$ for $4-7$ days. For the drug susceptibility test a suspension of grown bacteria was used, in PBS, manifesting density 2 in $\mathrm{McF}$ scale. The cultured strains were identified based on colony morphology, Gram staining and urease and catalase tests. All the research protocols were reviewed and approved by the Ethics Committee of the Poznan University of Medical Sciences, Poland. 
Susceptibility to amoxicillin (AMX), clarithromycin (CL), tetracycline (TC) and metronidazole (MTZ) was determined by E-test (AB Biodisc; Solna). A strip was placed on Columbia agar supplemented with $7 \%$ of sheep blood with pre-plated, examined strain of $H$. pylori. The incubation was performed in microaerophilic conditions (Generbag or Generbox microaer; bioMerieux) at the temperature of $37^{\circ} \mathrm{C}$ for 3 days. Resistance breakpoints of $H$. pylori were used and interpreted according to CLSI (AMX - $0.5 \mathrm{mg} / \mathrm{L}, \mathrm{CL}-1 \mathrm{mg} / \mathrm{L}, \mathrm{TC}-4$ $\mathrm{mg} / \mathrm{L}, \mathrm{MTZ}-8 \mathrm{mg} / \mathrm{L}$ ) and according to EUCAST (AMX - $0.12 \mathrm{mg} / \mathrm{L}, \mathrm{CL}-0.5$ $\mathrm{mg} / \mathrm{L}, \mathrm{TC}-1 \mathrm{mg} / \mathrm{L}, \mathrm{MTZ}-8 \mathrm{mg} / \mathrm{L})$.

\section{Statistical methods}

Statistical analysis was performed using Fisher's exact test. A p-value higher than 0.05 was considered non-significant.

\section{Results}

All examined H. pylori strains in both groups were susceptible to amoxicillin (AMX). Group 1 contained no strains resistant to tetracycline (TC), in turn the group comprised $9 \%$ of strains resistant to clarithromycin (CL) and $36 \%$ of strains resistant to metronidazole (MTZ). On the other hand, Group 2 contained $31 \%$ of strains resistant to CL and $83 \%$ of strains resistant to MTZ. Resistance to TC on Group 2 depended on the applied criteria: according to EUCAST it involved $14 \%$ but none after CLSI recommendations. In line with the currently binding criteria of EUCAST, a significant increase in their content of strains resistant to TC $(\mathrm{p}<0.0001)$, CL $(\mathrm{p}=0.0003)$ and MTZ $(\mathrm{p}<0.0001)$ was detected between the two groups. The results obtained in both groups of studied strains are presented in Table I.

\section{Discussion}

In treatment of infections with $H$. pylori, the universal and still applied triple therapy is also defined as first-line therapy [5]. At present several factors are known which may reduce efficacy of the standard triple therapy: they include the high bacterial load, type of strain, high gastric acidity and increase in $H$. pylori resistance to antibiotics [9]. 
Table I. Resistance of Helicobacter pylori to AMX, CL, TC and MTZ in Group 1 (years 1998/1999) and Group 2 (years 2013/2014) according to EUCAST breakpoints

\begin{tabular}{lccc}
\hline & \multicolumn{2}{c}{$\begin{array}{c}\text { Percent of resistance in studied groups } \\
\text { of } H . \text { pylori strains }\end{array}$} & $\begin{array}{c}\text { Level of significance; } \\
\text { Antibacterial drug }\end{array}$ \\
\cline { 2 - 3 } & $\begin{array}{c}\text { Group 1 } \\
(1998 / 1999)\end{array}$ & $\begin{array}{c}\text { Group } 2 \\
(2013 / 2014)\end{array}$ & 1.0000 \\
\hline AMX & $0 \%$ & $0 \%$ & $0.0003^{*}$ \\
CL & $9 \%$ & $31 \%$ & $<0.0001^{*}$ \\
TC & $0 \%$ & $14 \%$ & $<0.0001^{*}$ \\
MTZ & $36 \%$ & $83 \%$ & \\
\hline
\end{tabular}

*significantly different between both groups.

In the conducted experiments none of the analysed strains manifested resistance to AMX. Nevertheless, in recent decade efficacy of eradication in H. pylori infection following the triple therapy was found to be reduced [10]. In such a context it remains difficult to interpret the demonstrated susceptibility of isolates to AMX in both studied groups. Possibly, the clinical resistance of H. pylori to AMX depends on bioaccessibility of the drug in gastric mucosa linked to its acidity [9]. Our results have been confirmed by other European data, documenting the level of resistance to amoxicillin of $0-0.9 \%$ [11]. A high proportion of primary amoxicillin resistance (13.6-59\%) was detected in Africa, Asia and South America [12-14].

In the studies presented above the proportion of strains resistant to clarithromycin in West Poland was found to comprise at present $31 \%$ and it increased by $22 \%$ within recent 15 years. In addition, recent data indicate that genotype studies (by PCR) allow for a markedly more frequent detection of resistance to clarithromycin than using phenotypic determination (by E-test) [15]. In Europe clarithromycin resistance manifests a variable level and in strains isolated from adult patients in 2008-2009 on averaged at $17.5 \%$. The highest proportion of strains resistant to clarithromycin was detected in Greece (42\%) and the lowest one in Holland $(5.6 \%)[11,16]$. In Poland, resistance to clarithromycin was gradually increasing, amounting in 1998/1999 to 9\% [17], in 2001-2009 already to 15.4$28 \%$ [18-20]. In studies presented here we have demonstrated $31 \%$ resistance of H. pylori strains to clarithromycin, which might point to a continuous increase in resistance to the drug. The increase in resistance to clarithromycin was observed also in strains isolated from children, linked to the widespread application of macrolide antibiotics in paediatrics [19,21,22]. Therefore, clarithromycin should not be applied in treatment of $H$. pylori infections without earlier estimation of susceptibility to the drug. 
In the conducted studies a significant increase was noted in proportion of strains resistant to TC $(0 \%$ in Group 1 versus $14 \%$ in Group 2). However, the data were obtained using interpretation criteria of EUCAST. On the other hand, using criteria of CLSI, no strain in either of the two groups manifested resistance to TC. Using CLSI criteria, other authors [11, 23, 24] demonstrated in Europe persistence of low resistance to TC (0-2.6\%). Since interpretation criteria of EUCAST related to resistance of $H$. pylori to TC may result in divergent results, as compared to those obtained in line with the earlier CLSI recommendations, the matter requires verification.

In this study we have for the first time demonstrated a dramatic increase in resistance to metronidazole (83\%) among strains isolated in 2013/2014. A similarly high frequency $(50-80 \%)$ of strains resistant to the chemotherapeutic agent was noted in developing countries [12]. Between 2000-2010 in various European countries $20-43.8 \%$ of strains were found to be resistant to metronidazole. The highest proportion of resistant strains was demonstrated in Italy (59.3\%) and in countries of Central and Western Europe (>40\%) [11, 25]. In Poland, in 1998/1999 resistance to metronidazole was manifested by $36 \%$ strains [17] and the proportion systematically grew in subsequent years, including 41.7-58.5\% in 2000-2004 [19, 20], and up to $66.7 \%$ in certain southern regions of Poland in 2008-2011 [26]. It seems probable that the significant increase in resistance to metronidazole in Poland reflects a sequel of using the drug not only in treatment of gynaecological and dental diseases but also as a drug for eradication of parasitic infections [22].

Thus, in West Poland, within recent 15 years a dramatic increase was noted in $H$. pylori strains resistant to metronidazole as well as in percentage of strains resistant to clarithromycin. In parallel, the EUCAST criteria for interpretation of H. pylori resistance to tetracycline require verification.

\section{Acknowledgement}

The research was supported by a grant from Poznań University of Medical Sciences, Poland (502-01-02206316-02658).

\section{Conflicts of Interest}

The authors declare that there are no conflicts of interest. 


\section{References}

1. Malaty, H. M.: Epidemiology of Helicobacter pylori infection. Best Pract Res Clin Gastroenterol 21, 205-214 (2007).

2. Eusebi, L. H., Zagari, R. M., Bazzoli, F.: Epidemiology of Helicobacter pylori infection. Helicobacter 19(Suppl 1), 1-5 (2014).

3. Makola, D., Peura, D. A., Crowe, S. E.: Helicobacter pylori infection and related gastrointestinal diseases. J Clin Gastroenterol 41(6), 548-558 (2007).

4. Malfertheiner, P., Megraud, F., O’Morain, C., Bazzoli, F., El-Omar, E., Graham, D., Hunt, R., Rokkas, T., Vakil, N., Kuipers, E. J.: Current concepts in the management of Helicobacter pylori infection: The Maastricht III Consensus Report. Gut 56, 772-781 (2007).

5. Malfertheiner, P., Megraud, F., O’Morain, C. A., Atherton, J., Axon, A. T., Bazzoli, F., Gensini, G. F., Gisbert, J. P., Graham, D. Y., Rokkas, T., El-Omar, E. M., Kuipers, E. J., European Helicobacter Study Group: Management of Helicobacter pylori infection - The Maastricht IV/ Florence Consensus Report. Gut 61(5), 646-664 (2012).

6. Feng, L., Wen, M. Y., Zhu, Y. J., Men, R. T., Yang, L.: Sequential therapy or standard triple therapy for Helicobacter pylori infection: An updated systematic review. Am J Ther [Epub ahead of print] (2015).

7. Graham, D. Y., Fischbach, L.: Helicobacter pylori treatment in the era of increasing antibiotic resistance. Gut 59(8), 1143-1153 (2010).

8. Mégraud, F.: H. pylori antibiotic resistance: Prevalence, importance, and advances in testing. Gut 53(9), 137-184 (2004).

9. Sachs, G., Weeks, D. L., Melchers, K., Scott, D. R.: The gastric biology of Helicobacter pylori. Annu Rev Physiol 65, 349-369 (2003).

10. O'Connor, A., Vaira, D., Gisbert, J. P., O'Morain, C.: Treatment of Helicobacter pylori infection 2014. Helicobacter 19(Suppl 1), 38-45 (2014).

11. Megraud, F., Coenen, S., Versporten, A., Kist, M., Lopez-Brea, M., Hirschl, A. M., Andersen, L. P., Goossens, H., Glupczynski, Y., Study Group participants: Helicobacter pylori resistance to antibiotics in Europe and its relationship to antibiotic consumption. Gut 62(1), 34-42 (2013).

12. Boyanova, L., Mitov, I.: Geographic map and evolution of primary Helicobacter pylori resistance to antibacterial agents. Expert Rev Anti Infect Ther 8(1), 59-70 (2010).

13. Nishizawa, T., Suzuki, H., Tsugawa, H., Muraoka, H., Matsuzaki, J., Hirata, K., Ikeda, F., Takahashi, M., Hibi, T.: Enhancement of amoxicillin resistance after unsuccessful Helicobacter pylori eradication. Antimicrob Agents Chemother 55(6), 3012-3014 (2011).

14. Abadi, A. T., Taghvaei, T., Mobarez, A. M., Carpenter, B. M., Merrell, D. S.: Frequency of antibiotic resistance in Helicobacter pylori strains isolated from the northern population of Iran. J Microbiol 49(6), 987-993 (2011).

15. De Francesco, V., Zullo, A., Ierardi, E., Giorgio, F., Perna, F., Hassan, C., Morini, S., Panella, C., Vaira, D.: Phenotypic and genotypic Helicobacter pylori clarithromycin resistance and therapeutic outcome: Benefits and limits. J Antimicrob Chemother 65(2), 327332 (2010).

16. Karamanolis, G. P., Daikos, G. L., Xouris, D., Goukos, D., Delladetsima, I., Ladas, S. D.: The evolution of Helicobacter pylori antibiotics resistance over 10 years in Greece. Digestion 90, 229-231 (2014). 
17. Andrzejewska, E., Szkaradkiewicz, A., Karpiński, T.: Antimicrobial resistance of Helicobacter pylori clinical strains in the last 10 years. Pol J Microbiol 58(4), 301-305 (2009).

18. Karczewska, E., Wojtas-Bonior, I., Sito, E., Zwolińska-Wcisło, M., Budak, A.: Primary and secondary clarithromycin, metronidazole, amoxicillin and levofloxacin resistance to Helicobacter pylori in southern Poland. Pharmacol Rep 63(3), 799-807 (2011).

19. Dzierżanowska-Fangrat, K., Rożynek, E., Celińska-Cedro, D., Jarosz, M., Pawłowska, J., Szadkowski, A., Budzyńska, A., Nowak, J., Romańczuk, W., Prosiecki, R., Jóźwiak, P., Dzierzanowska, D.: Antimicrobial resistance of Helicobacter pylori in Poland: A multicentre study. Int J Antimicrob Agents 26(3), 230-234 (2005).

20. Iwanczak, B., Laszewicz, W., Iwanczak, F., Dzierzanowska-Fangrat, K., Rozynek, M., Dzierzanowska, D., Gosciniak, G., Dlugosz, J.: Genotypic and clinical differences of seropositive Helicobacter pylori children and adults in the Polish population. J Physiol Pharmacol 65(6), 801-807 (2014).

21. Rożynek, E., Dzierżanowska-Fangrat, K., Celińska-Cedro, D., Jóźwiak, P., Madaliński, K., Dzierzanowska, D.: Primary resistance of Helicobacter pylori to antimicrobial agents in Polish children. Acta Microbiol Pol 51(3), 255-263 (2002).

22. Gerrits, M. M., van Vliet, A. H., Kuipers, E. J., Kusters, J. G.: Helicobacter pylori and antimicrobial resistance: Molecular mechanisms and clinical implications. Lancet Infect Dis 6(11), 699-709 (2006).

23. Boyanova, L., Ilieva, J., Gergova, G., Evstatiev, I., Nikolov, R., Mitov, I.: Living in Sofia is associated with a risk for antibiotic resistance in Helicobacter pylori: A Bulgarian study. Folia Microbiol (Praha) 58(6), 587-591 (2013).

24. O'Connor, A., Taneike, I., Nami, A., Fitzgerald, N., Ryan, B., Breslin, N., O’Connor, H., McNamara, D., Murphy, P., O'Morain, C.: Helicobacter pylori resistance rates for levofloxacin, tetracycline and rifabutin among Irish isolates at a reference centre. Ir J Med Sci 182(4), 693-695 (2013).

25. Saracino, I. M., Zullo, A., Holton, J., Castelli, V., Fiorini, G., Zaccaro, C., Ridola, L., Ricci, C., Gatta, L., Vaira, D.: High prevalence of primary antibiotic resistance in Helicobacter pylori isolates in Italy. J Gastrointestin Liver Dis 21(4), 363-365 (2012).

26. Gościniak, G., Biernat, M., Grabińska, J., Bińkowska, A., Poniewierka, E., Iwańczak, B.: The antimicrobial susceptibility of Helicobacter pylori strains isolated from children and adults with primary infection in the Lower Silesia Region, Poland. Pol J Microbiol 63(1), 57-61 (2014). 